Japan. J. Med. Sci. Biol., 27, 19-33, 1974.

\title{
ENTEROPATHOGENICITY AND ENTEROTOXIGENICITY OF HUMAN ENTEROPATHOGENIC ESCHERICHIA COLI
}

\author{
RIICHI SAKAZAKI, KAZUMICHI TAMURA, AKIKO NAKAMURA, \\ TAKESHI, KURATA*, AKIRA GOHDA** \\ AND SATOSHI TAKEUCHI** \\ The 1st Department of Bacteriology and *Department of Pathology, National \\ Institute of Health, Kamiosaki, Shinagawa-ku, Tokyo 141, and \\ **The Kitasato Institute, Shirogane, Minato-ku, Tokyo 108, Japan
}

(Received: October 31, 1973)

SUMMARY : The mechanism of enteropathogenicity of human enteropathogenic Escherichia coli (EEC) was studied by ligated gut loop tests in rabbits, keratoconjunctival tests in guinea pig eyes and feeding tests on human volunteers, and by examining for their ability to penetrate into HeLa cells.

Strains of invasive EEC (Shigella-like) serotypes produced inflammatory changes and fluid accumulation in the ligated rabbit gut loop, keratoconjunctivitis in guinea pig eyes, and penetration into HeLa cells. With few exceptions, no enterotoxic activity was demonstrated with cell-free filtrates of broth cultures. It was considered that EEC strains of this group may probably cause disease in man by a mechanism similar to that of Shigella organisms, and that enterotoxin production may not be concerned with the pathogenicity of these organisms.

When strains of noninvasive EEC including 27 OK group serotypes were studied, 46 of 67 cultures employed produced fluid accumulation and histopathological changes in ligated gut loop tests in rabbits, whereas none of them induced keratoconjunctivitis in guinea pig eyes nor penetration into HeLa cells. In addition, cell-free filtrates from broth cultures of 12 out of 20 strains produced alterations similar to those caused by living culture in the gut loop tests. When $\mathrm{R}$-state cultures derived from three strains of noninvasive EEC serotypes were tested for their activity in rabbit gut loops, it was demonstrated that the mutants no longer had the ability to produce positive gut loop reactions, although filtrates of the $\mathrm{R}$ cultures were still able to cause pathological alterations in the loops. Cell cultures killed by acetone, chloroform, or heat failed to give positive gut loop reactions.

Positive gut loop reactions were also induced by some strains not belonging to the recognized EEC serotypes originating from sources other than gastroenteritis patients.

Nine strains consisting of four of noninvasive EEC and five enterotoxigenic strains not belonging to the recognized EEC serotypes were tested with human volunteers. All the former strains caused acute gastroenteritis in the volunteers, while the latter elicited on response.

These results suggest that enterotoxin production is not concerned in the mechanism of enteropathogenicity of noninvasive EEC. On the other hand, it seemed that the ability to multiply in the intestine is essential in the enteropathogenicity of noninvasive EEC strains, although an enterotoxic substance demonstrated in cell-free filtrates may play a role in the development of gastroenterit is.

\footnotetext{
坂崎利一・田村和満・中村明子（国立予防衛生研究所 細菌第一部）

* 倉田 毅 (国立予防衛生研究所 病理部)

** 合田 朗- 武内 聡 (北里研究所 東京都港区白金 5-9-1)
} 


\section{INTRODUCTION}

There is growing evidence that some serotypes of Escherichia coli can cause acute intestinal disturbance in children and adults as well as infants. Sakazaki, Tamura and Saito (1967) recognized that these serotypes of enteropathogenic E. coli (EEC) could be divided into Salmonella-like and Shigella-like groups according to the symptoms they produced. Thus, serotypes in the Salmonella-like group caused gastroenteritis, whereas those in the Shigella-like group a dysentery-like syndrome. Later, Ogawa, Nakamura and Sakazaki (1968) showed that cultures of the Shigellalike group of EEC possessed invasive properties characteristic of Shigella strains.

Recent work suggested that some other strains of $E$. coli not belonging to the recognized EEC serotypes could produce an enterotoxin which seemed to be associated with diarrhea (Sack et al., 1971; Gorbach, 1971; Etkin and Gorbach, 1971). Most studies on the enterotoxigenicity of human $E$. coli strains have been carried out by cholera investigators, comparing with that of Vibrio cholerae. Subsequently, it was thought that enterotoxin production may be the most important etiological factor in human diarrhea produced by noninvasive (Salmonella-like) EEC, and therefore perhaps in the same category as cholera. So far, however, all the reported cases of infection with EEC in Europe and in Japan have been of gastroenteritis or colitis associated with inflammation of the gastrointestinal tract, and no cases of cholera-like illness have been recognized.

During the last 15 years, experiments in animals and in human volunteers have been carried out with hundreds of strains of $E$. coli to study their enteropathogenicity and its relationship to enterotoxigenicity. It is the purpose of this paper to summarize the results of these experiments.

\section{MATERIALS AND METHODS}

Strains studied: A total of 361 strains were collected during the period 19551973. The sources of these strains were as follows: Diarrheal stools, 235; normal stcols, 102; urine, 20; blood and other specimens, 4 . Of the 235 strains from patients with diarrhea, 12 were received from other investigators as follows: from Dr. J. Taylor, London, strains E126/63 (O26: K60), E65/56 (O26: K60), G193/58 (O55: K59), Aberdeen (055:K59), and D5301 (O128: K67) from cases of infantile diarrhea; from Dr. S. L. Gorbach, Chicago, strains 339 (O15: H11) and 410-G (O78: K80) from cholera syndrome; from Dr. R. B. Sack, Portland, an untypable strain from cholera syndrome; and from Dr. F. Фrskov, Copenhagen, strains E519 (O148: H28), E1514 (O154: K94), E1529 (O155: K.), and E1585 (O156: K.) from diarrhea. The remaining 223 strains from diarrheal stools included 82 described in previous papers (Sakazaki et al., 1967; Sakazaki, Tamura and Nakamura, 1974 a). The 20 strains from urinary infection were received from various hospitals for identification. Four virulent strains from non-intestinal infections were described by and obtained from Erlandson, Nemer, and Pearson (1964). The 102 strains from normal stools were isolated by the present authors.

All strains were maintained at room temperature by the dried gelatin method of Stamp (1947).

Inocula for animal tests: Early in the study, heart infusion broth cultures were 
used as inocula for animal tests. Later, since it was found that the culture medium influenced the virulence or toxicity of the organisms, Nakamura, Sakazaki, and Tamura (unpublished) devised a medium giving better results in animal tests than penassay broth (Difco), heart infusion broth (Difco), brain heart infusion (BBL), trypticase soy broth (BBL), and syncase broth of Finkelstein et al. (1966) with cultures of EEC, Shigella, and Salmonella. This medium, Myosate-Mannitol-Virulence broth (MMV) consisted of $1 \%$ myosate (BBL), $0.1 \%$ mannitol, $0.35 \%$ sodium chloride, $0.368 \%$ dipotassium phosphate, and $0.132 \%$ of monopotassium phosphate, adjusted to $\mathrm{pH} 7.0$.

For tests with living cultures, opaque, smooth colonies of test strains from plates of blood agar base were inoculated into MMV broth. After overnight incubation at $37 \mathrm{C}, 1.0 \mathrm{ml}$ of the culture was transferred to $10.0 \mathrm{ml}$ of $\mathrm{MMV}$ broth, which was shaken for $6 \mathrm{hr}$ in a water bath at $37 \mathrm{C}$. Plate counts indicated that about $10^{8}$ viable cells were present in $1.0 \mathrm{ml}$ of the 6 -hr broth culture.

For determination of enterotoxic activity of culture filtrates, MMV broth was also employed, because in preliminary studies it was superior to syncase broth. After inoculation with $10.0 \mathrm{ml}$ of an overnight broth culture, a $500-\mathrm{ml}$ flask containing 100 $\mathrm{ml}$ of MMV broth was incubated for $24 \mathrm{hr}$ at $37 \mathrm{C}$ with shaking, and the culture then centrifuged at $21,220 \times g$. The supernatant fluid was filtered through a Milipore membrane $(0.45 \mu)$ and lyophilized. Before use, the lyophilized filtrate was reconstituted to $1 / 10$ of its original volume with sterile distilled water containing $100 \mathrm{mcg} / \mathrm{ml}$ each of neomycin and polymyxin B.

Ligated gut loop tests in rabbits: These were carried out by a modification of the method of De and Chatterjee (1953). After starvation for $24 \mathrm{hr}$, rabbits were anaesthetized with barbiturates; the small intestine, taken midway between the upper and lower ends, was isolated with two silk ligatures. The contents of the isolated segment were washed out with about $300 \mathrm{ml}$ of sterile saline introduced from the upper end with a syringe; the efferent fluid was drained through a thin glass canula inserted in the lower end. Washing was continued until the efferent fluid became clear and colorless. The isolated loop was then divided into seven small segments with string ligatures; $1.0 \mathrm{ml}$ of a material for testing inoculated into one segment. The injection site was ligated to prevent leakage of the inoculum through the needle hole. Test inocula were injected into the $1 \mathrm{st}, 3 \mathrm{rd}, 5$ th and 7 th small segments, and the 2 nd, 4 th and 6 th segments were left as buffers. The abdomen was closed by sutures. A rabbit was thus inoculated with four test cultures; three or four animals were used to test each inoculum. After 16 to $24 \mathrm{hr}$, each animal was killed and examined for the presence or absence of dilatation in test segments as well as for macroscopic and microscopic changes in the intestinal mucosa. The activity of a given strain was regarded as positive if at least one animal tested showed a reaction.

Keratoconjunctival tests in guinea pigs: One drop, approx. $0.05 \mathrm{ml}$, of a saline suspension containing about $10^{8}$ viable cells of a test culture grown on MMV or penassay agar was inoculated into the conjunctival sac of the guinea pig. The animals were examined for a period of 5 days for evidence of keratoconjunctivitis (Selény, 1955). Two animals were used to test each strain.

HeLa cell culture tests: The tests were carried out by the method of LaBrec et al. (1964). HeLa cell monolayers grown on cover slips were infected with washed bacterial cells suspended in saline at a final concentration of $10^{8}$ per ml. Cover slips were removed in 7 and $18 \mathrm{hr}$ and examined for bacterial penetration and cell 
deaths.

Human volunteer tests: Volunteer tests were performed with some strains to confirm their enteropathogenicity. Healthy volunteers, aged 20 to 33 years, ingested in the morning about $10^{7}-10^{8}$ viable cells of each of the test strains, harvested from overnight heart infusion agar cultures, in $100 \mathrm{ml}$ of milk. They were observed clinically for 4 days.

\section{RESULTS}

At first, the 361 strains were typed serologically with the $\mathrm{O}$ and $\mathrm{K}$ diagnostic antisera for EEC serotypes described by Sakazaki et al. (1967, 1974 a). The strains were also divided into three groups; invasive (Shigella-like) and non-invasive (Salmonella-like) EEC serotypes; and a group of serotypes nct belonging to recognized EEC.

\section{Animal tests}

a) Invasive EEC serotypes. Of the 361 strains tested with $\mathrm{O}$ and $\mathrm{K}$ EEC antisera, 20 belonged to the invasive serotypes reported by Sakazaki et al. (1967, 1974 a). Keratoconjunctival tests in guinea pigs, ligated gut loop tests in rabbits, and bacterial penetration into HeLa cell cultures were then carried out with these 20 strains. As shown in Table I, 11 of the 20 strains gave positive results in all three tests, other three strains gave no reaction in any of these tests, and the remaining six strains induced positive reactions in guinea pig eye and rabbit gut loop tests, but showed no evidence of penetration into HeLa cells.

The 11 strains giving reactions in all three tests were studied further for evidence of enterotoxic activity with culture filtrates. The results are shown in Table II. Cell-free filtrates of only two cultures, 1186-68 (O25:K1) and 1184-68 (O152:K.), induced fluid accumulation in rabbit gut loops. These two strains caused histopathological changes in the intestinal mucosa of the dilated loop similar to those produced by filtrate of a noninvasive EEC culture mentioned later. The filtrates caused no reaction in guinea pig eyes or HeLa cell cultures.

b) Noninvasive EEC serotypes. Of the 361 strains studied, 62 belonged to 22 different O group serotypes previously reported by Sakazaki et al. (1967, 1974 a). In addition, other five strains comprising one culture each of $O$ groups 154, 155, and 156, reported by $Ф$ rskov et al. (1973), and of $\mathrm{O}$ group 15 and an unidentified $O$ group

\section{TABLE I}

Reactivity to invasive enteropathogenic Escherichia coli of guinea pig eye, ligated rabbit gut loop and HeLa-cell culture

\begin{tabular}{cccc}
\hline Number of & $\begin{array}{c}\text { Keratoconjunctival } \\
\text { reaction in } \\
\text { guinea pigs }\end{array}$ & $\begin{array}{c}\text { Reaction of } \\
\text { ligated gut loop } \\
\text { in rabbits }\end{array}$ & $\begin{array}{c}\text { Invasion of } \\
\text { HeLa cells }\end{array}$ \\
\hline 11 & + & + & + \\
6 & + & + & - \\
3 & - & - & - \\
\hline
\end{tabular}


TABLE II

Reactivity to living cultures and culture filtrates of invasive enteropathogenic Escherichia coli serotypes of ligated gut loops in rabbits

\begin{tabular}{llcc}
\hline \multirow{2}{*}{ OK group } & \multirow{2}{*}{ Strain } & \multicolumn{2}{c}{ Reaction of ligated gut loops } \\
\cline { 3 - 4 } & & Living culture & Culture filtrate \\
\hline O25:K1 & $1186-68$ & $2 / 2^{*}$ & $1 / 2$ \\
O28a,c:K73 & $211-65$ & $2 / 2$ & $0 / 2$ \\
O112a,c: 666 & $1135-66$ & $2 / 2$ & $0 / 2$ \\
O124:K72 & $877-65$ & $4 / 4$ & $0 / 4$ \\
O124:K72 & $916-65$ & $4 / 4$ & $0 / 4$ \\
O136:K78 & $633-65$ & $2 / 2$ & $0 / 2$ \\
O136:K78 & $1193-65$ & $4 / 4$ & $0 / 4$ \\
O143:K. & $905-65$ & $4 / 4$ & $0 / 8$ \\
O144:K. & $632-65$ & $4 / 4$ & $0 / 10$ \\
O144:K. & $637-65$ & $4 / 4$ & $0 / 4$ \\
O152:K. & $1184-68$ & $4 / 4$ & $2 / 4$ \\
\hline
\end{tabular}

* The dominator indicates the number of tests; the numerator the number of positive reactions.

reported by Sack et al. (1971) were also included in this category; thus a total of 67 cultures belonged to noninvasive EEC serotypes.

When living cultures of the EEC group were inoculated into ligated gut loops, 45 of the 67 cultures produced dilatation and histopathological changes in one or more animals (Table III). There was good correlation between dilatation of loops and histopathological changes in the intestinal mucosa in most instances. In some cases, however, no dilatation occurred in the loop, although marked histopathological cahnges were seen in the mucosa.

Twenty cultures belonging to $13 \mathrm{O}$ group serotypes indicated in Table IV were selected at random for studying their toxigenicity. Of these 20 strains, culture filtrates from 13 produced dilatation in one or more animals, thus suggesting enterotoxin production by these organisms. Fluid accumulation alone was observed in some loops, but in most instances fluid accumulation was accompanied with pathological changes in the intestinal mucosa. In contrast to occasional cases with living cultures, however, no pathological changes without dilatation were observed with culture filtrates.

When the results of gut loop tests with living culture of noninvasive EEC serotypes were compared with the invasive serotypes, variation in reactions with a given strain occurred more frequently. As indicated in Takles I, II, and III, all loop tests with living cultures of virulent invasive strains showed positive responses, whereas the response was infrequent with noninvasive serotypes. Variation in results was also frequently observed among strains of the same serotypes of noninvasive EEC.

By several passages through a semisolid medium containing $3 \%$ homologous $\mathrm{O}$ antiserum, R-state cultures were obtained from three S-state strains of $\mathrm{O}$ groups 27 , 
TABLE III

Reactivity to living cultures of noninvasive enteropathogenic Escherichia coli serotypes of ligated gut loops in rabbits

\begin{tabular}{|c|c|c|c|}
\hline OK group & $\begin{array}{l}\text { Number of } \\
\text { strains tested }\end{array}$ & Positive reactions & $\begin{array}{l}\text { Number of } \\
\text { positive } \\
\text { strains }\end{array}$ \\
\hline $\mathrm{O} 6: \mathrm{K}$ & 3 & $1 / 32 / 3 \quad 0 / 4^{*}$ & 2 \\
\hline $\mathrm{O} 6: \mathrm{K} 62$ & 1 & $1 / 4$ & 1 \\
\hline O18:K76 & 2 & $1 / 2 \quad 1 / 3$ & 2 \\
\hline O18:K77 & 4 & $\begin{array}{llll}2 / 3 & 0 / 4 & 1 / 3 & 1 / 4\end{array}$ & 3 \\
\hline $\mathrm{O} 20: \mathrm{K} 84$ & 6 & $\begin{array}{llllll}2 / 3 & 0 / 3 & 0 / 3 & 1 / 3 & 2 / 4 & 0 / 3\end{array}$ & 3 \\
\hline $\mathrm{O} 26: \mathrm{K} 60$ & 6 & $\begin{array}{llllll}1 / 3 & 0 / 3 & 4 / 4 & 0 / 2 & 2 / 2 & 0 / 2\end{array}$ & 3 \\
\hline $\mathrm{O} 27: \mathrm{K}$ & 4 & $\begin{array}{llll}1 / 3 & 1 / 3 & 1 / 3 & 1 / 3\end{array}$ & 4 \\
\hline $\mathrm{O} 44: \mathrm{K} 74$ & 3 & $\begin{array}{llll}3 / 3 & 0 / 3 & 1 / 3\end{array}$ & 2 \\
\hline O55:K59 & 4 & $2 / 3 \quad 0 / 3 \quad 3 / 6 \quad 1 / 4$ & 3 \\
\hline $\mathrm{O} 78: \mathrm{K} 80$ & 3 & $\begin{array}{lll}1 / 3 & 0 / 3 & 0 / 6\end{array}$ & 1 \\
\hline $\mathrm{O} 86: \mathrm{K} 61$ & 2 & $3 / 30 / 3$ & 1 \\
\hline $\mathrm{O} 86: \mathrm{K} 62$ & 1 & $0 / 3$ & 0 \\
\hline O111:K58 & 2 & $1 / 32 / 4$ & 2 \\
\hline O114:K90 & 1 & $2 / 3$ & 1 \\
\hline $\mathrm{O} 119: \mathrm{K} 66$ & 3 & $2 / 3 \quad 1 / 3 \quad 0 / 3$ & 2 \\
\hline $\mathrm{O} 125: \mathrm{K} 70$ & 2 & $1 / 3 \quad 0 / 3$ & 1 \\
\hline $\mathrm{O} 126: \mathrm{K} 71$ & 2 & $2 / 3 \quad 1 / 3$ & 2 \\
\hline $\mathrm{O} 127: \mathrm{K} 63$ & 1 & $0 / 3$ & 0 \\
\hline $\mathrm{O} 128: \mathrm{K} 67$ & 4 & $1 / 3 \quad 0 / 2 \quad 2 / 3 \quad 1 / 2$ & 3 \\
\hline $\mathrm{O} 142: \mathrm{K} 86$ & 3 & $1 / 3 \quad 1 / 30 / 3$ & 2 \\
\hline $\mathrm{O} 146: \mathrm{K}$ & 1 & $1 / 4$ & 1 \\
\hline $\mathrm{O} 148: \mathrm{K}$ & 4 & $\begin{array}{llll}3 / 3 & 2 / 3 & 1 / 3 & 3 / 4\end{array}$ & 4 \\
\hline $\mathrm{O} 154: \mathrm{K}$ & 1 & $0 / 2$ & 0 \\
\hline $\mathrm{O} 155: \mathrm{K}$ & 1 & $0 / 2$ & 0 \\
\hline $\mathrm{O} 156: \mathrm{K}$ & 1 & $0 / 2$ & 0 \\
\hline O15:K (Sack) & 1 & $2 / 4$ & 1 \\
\hline Untypable (Sack) & 1 & $4 / 6$ & 1 \\
\hline Total & 67 & & 46 \\
\hline
\end{tabular}

* The dominator indicates the number of tests; the numerator the number of positive reactions.

55, and 148 which produced positive gut loop reactions with either living culture or culture filtrate. When the three R-mutant cultures were tested for their response in rabbit gut loop, it was demonstrated, as shown in Table $\mathrm{V}$, that living cultures of these $\mathrm{R}$ mutants no longer had the ability possessed by the original S-state cultures 
to prcduce positive reactions in the test, whereas their culture filtrates were still able to cause pathological alterations in the loops.

TABLE IV

Reactivity to culture filtrates of noninvasive enteropathogenic Escherichia coli serotypes of ligated gut loops in rabbits

\begin{tabular}{llcc}
\hline OK group & Strain & $\begin{array}{c}\text { Living } \\
\text { culture }\end{array}$ & $\begin{array}{c}\text { Culture } \\
\text { filtrate }\end{array}$ \\
\hline O18:K76 & $3126-69$ & $2 / 4^{*}$ & $1 / 6$ \\
O18:K77 & $469-71$ & $1 / 4$ & $3 / 4$ \\
O20:K84 & $466-71$ & $2 / 4$ & $3 / 4$ \\
O20:K84 & $467-71$ & $0 / 2$ & $0 / 2$ \\
O26:K60 & $\mathrm{E} 126-63$ & $4 / 4$ & $1 / 5$ \\
O26:K60 & E65-56 & $0 / 2$ & $0 / 10$ \\
O26:K60 & $1018-64$ & $0 / 2$ & $1 / 2$ \\
O26:K60 & $1056-68$ & $2 / 2$ & $2 / 2$ \\
O27:K. & $63-68$ & $1 / 3$ & $0 / 2$ \\
O27:K. & $133-68$ & $1 / 3$ & $1 / 3$ \\
O55:K59 & G193-58 & $3 / 6$ & $0 / 5$ \\
O55:K59 & Aberdeen & $1 / 4$ & $4 / 6$ \\
O78:K80 & $421-72$ & $0 / 6$ & $2 / 6$ \\
O128:K69 & E5301 & $1 / 2$ & $4 / 4$ \\
O142:K86 & $449-72$ & $1 / 2$ & $0 / 4$ \\
O148:K. & $441-72$ & $3 / 4$ & $4 / 6$ \\
O154:K. & $558-72$ & $0 / 2$ & $1 / 2$ \\
O155:K. & $559-72$ & $0 / 2$ & $0 / 2$ \\
O156:K. & $560-72$ & $0 / 2$ & $0 / 2$ \\
Unknown & Sack & $4 / 6$ & $9 / 14$ \\
\hline
\end{tabular}

* The dominator indicates the number of tests; the numerator the number of positive reactions.

\section{TABLE V}

Reactivity to $S$ - and $R$ - state cultures of some enteropathogenic Escherichia coli strains of ligated gut loops in rabbits

\begin{tabular}{lccc}
\hline Serotype & $\begin{array}{c}\text { Antigenic } \\
\text { state }\end{array}$ & \multicolumn{2}{c}{ Ligated gut loop reactivity } \\
\cline { 3 - 4 } & $\begin{array}{c}\text { Living } \\
\text { culture }\end{array}$ & Filtrate \\
\hline O27:K. & $\mathrm{S}$ & + & + \\
& $\mathrm{R}$ & - & + \\
O55:K59 & $\mathrm{S}$ & + & + \\
& $\mathrm{R}$ & - & + \\
O148:K. & $\mathrm{S}$ & + & + \\
& $\mathrm{R}$ & - & + \\
\hline
\end{tabular}


Whole cell lysates and cell cultures killed either with acetone or chloroform were prepared with three selected strains: G193-58 (O55:K59) which gave positive loop tests with living cultures but not with culture filtrates; an untypable strain from Sack which produced positive loop reactions with both living cells and culture filtrates; and 421-72 (O78:K80) which gave a positive loop reaction only with culture filtrate. With $1 \mathrm{mg}$ of whole cell lysate, $50 \mathrm{mg}$ of acetone-killed cells, or $10 \mathrm{mg}$ of chloroformkilled cells, the gut loop reaction was different among the strains (Table VI). All three preparations from G193-58, failed to give positive results. With strains 421-72 and Sack, the whole cell lysates produced positive loop reactions, whereas the killed cell preparations gave negative reactions. All three preparations from G193-58 failed to give positive results. With strains $427-72$ and Sack, the whole cell lysates produced positive loop reactions, whereas the killed cell preparations gave negative reactions.

All 67 strains of noninvasive EEC serotypes gave negative keratoconjunctival reactions in guinea pigs and had no effect on HeLa-cell cultures.

\section{TABLE VI}

Reactivity to whole cell lysate and killed cell preparations of some noninvasive enteropathogenic Escherichia coli of ligated gut loops in rabbits

\begin{tabular}{llllccc}
\hline \multirow{2}{*}{$\begin{array}{c}\text { Strain } \\
\text { No. }\end{array}$} & OK group & \multicolumn{5}{c}{ Reaction of ligated gut loops } \\
\cline { 3 - 7 } & $\begin{array}{c}\text { Living } \\
\text { culture }\end{array}$ & $\begin{array}{l}\text { Culture } \\
\text { filtrate }\end{array}$ & $\begin{array}{l}\text { Whole cell } \\
\text { lysate }\end{array}$ & $\begin{array}{c}\text { Acetone- } \\
\text { killed } \\
\text { culture }\end{array}$ & $\begin{array}{c}\text { Chloroform- } \\
\text { killed } \\
\text { culture }\end{array}$ \\
\hline G193-58 & O55:K59 & $2 / 6^{*}$ & $0 / 5$ & $0 / 2$ & $0 / 2$ & $0 / 2$ \\
Sack & Untypable & $4 / 6$ & $9 / 14$ & $2 / 2$ & $0 / 2$ & $0 / 2$ \\
$421-72$ & O78:K80 & $0 / 6$ & $2 / 6$ & $1 / 2$ & $0 / 4$ & $0 / 4$ \\
\hline
\end{tabular}

* The dominator indicates the number of tests; the numerator the number of positive reactions.

c) E. coli serotypes not belonging to any EEC group. During the last 15 eyars, 274 strains of $E$. coli not belonging to any recognized EEC serotypes were used for living culture and culture filtrate tests in ligated gut loops in rabbits. They consisted of 150 strains isolated from patients suffering from diarrhea, 100 strains from stools from healthy persons, 20 from urine of patients with urinary tract infections, and 4 strains from Erlandson, who isolated them from non-intestinal infections and described them as "human virulent E. coli" (Erlandson, Nemer, and Pearson, 1964). The results are summarized in Table VII.

With stool isolates, 8 of the 148 strains from patients with diarrhea and 7 of the 102 strains from healthy persons produced positive gut loop reactions; these strains belonged to $\mathrm{O}$ groups $2,3,4,6,8,19,25,51,62,68,75$, or 79 . Positive gut loop reactions were induced by one of the 20 strains from urinary infections and by 3 of the 4 human virulent strains. The former strain belonged to $O$ group 1 , and the three latter consisted of one $\mathrm{O}$ group 2 and one ungroupable strain. The enterotoxic activity was present in the supernatant fluid of their broth cultures of all the 4 strains, but none of them had any apparent effect in the keratoconjunctival reaction in guinea pigs or on HeLa-cell cultures. 
TABLE VII

Reactivity to Escherichia coli strains belonging to serotypes other than enteropathogenic group of ligated gut loops in rabbits

\begin{tabular}{lcc}
\hline \multicolumn{1}{c}{ Source } & $\begin{array}{c}\text { Number of } \\
\text { strains tested }\end{array}$ & $\begin{array}{c}\text { Number of positive } \\
\text { strains in gut } \\
\text { loop tests }\end{array}$ \\
\hline Diarrheal stools & 150 & $8^{*}$ \\
Normal stools & 100 & $7^{* *}$ \\
Urinary infection & 20 & $1^{* * *}$ \\
Blood & 4 & $3^{* * * *}$ \\
\hline
\end{tabular}

* O groups $2,3,4,8,25,62,75$, and 79 .

** O groups $2,6,19,25,51,68$, and 75 .

*** O group 1.

**** $\mathrm{O}$ group 2 and the other two ungroupable strains.

\section{Volunteer tests}

Eight strains were selected from those producing positive reactions in ligated gut loop tests in rabbits. Of these eight strains, two isolated from patients with enteritis belonged to $\mathrm{O}$ groups 44 and 142 of noninvasive EEC; three from patients with acute diarrhea belonged to $\mathrm{O}$ groups, 4, 8, and 79; two from normal stools were $\mathrm{O}$ groups 2 and 75 ; and one strain from non-intestinal infection was ungroupable. Milk containing $10^{8}$ viable cells of each strain was administered to two volunteers (Table

TABLE VIII

Reactions of human volunteers after ingestion of Escherichia coli

\begin{tabular}{|c|c|c|c|c|c|c|}
\hline \multirow{2}{*}{ Strain } & \multirow{2}{*}{ O group } & \multirow{2}{*}{ Source } & \multirow{2}{*}{$\begin{array}{l}\text { Reaction } \\
\text { of ligated } \\
\text { gut loop } \\
\text { in rabbits }\end{array}$} & \multicolumn{3}{|c|}{ Reaction of volunteer } \\
\hline & & & & Diarrhea & Fever & $\begin{array}{l}\text { Positive stool } \\
\text { isolation }\end{array}$ \\
\hline $231-67$ & $\mathrm{O} 142$ & Enteritis & $1 / 3^{*}$ & $2 / 2^{* *}$ & $1 / 2^{* *}$ & $2 / 2^{* * *}$ \\
\hline $212-58$ & $\mathrm{O} 44$ & Enteritis & $3 / 3$ & $2 / 2$ & $2 / 2$ & $2 / 2$ \\
\hline $11-18-53$ & $\mathrm{O} 4$ & Diarrhea & $2 / 3$ & $0 / 2$ & $0 / 2$ & $0 / 2$ \\
\hline $693-50$ & O79 & Diarrhea & $2 / 4$ & $0 / 2$ & $0 / 2$ & $0 / 2$ \\
\hline $68-50$ & O8 & Diarrhea & $1 / 3$ & $0 / 2$ & $0 / 2$ & $0 / 2$ \\
\hline $2192-1$ & $\mathrm{O} 2$ & Normal stools & $2 / 3$ & $0 / 2$ & $0 / 2$ & $0 / 2$ \\
\hline $469-54$ & $\mathrm{O} 75$ & Normal stools & $1 / 4$ & $0 / 2$ & $0 / 2$ & $0 / 2$ \\
\hline Mich-7 & UK & Blood & $1 / 2$ & $0 / 2$ & $0 / 2$ & $0 / 2$ \\
\hline
\end{tabular}

* The dominator indicates the number of tests; the numerator the number of positive reaction.

** The dominator indicates the number of volunteers tested; the numerator the number of volunteers with symptom.

*** The dominator indicates the number of volunteers tested; the numerator the number of positive isolation. 
VIII). Two strains of EEC serotypes caused enteritis 8 to $13 \mathrm{hr}$ after ingestion. The remaining six strains not belonging to any of the recognized EEC serotypes elicited no response in the volunteers, even though some of the strains were isolated from patients with diarrhea, and the organisms ingested were not recovered from stool specimens examined for 7 days after ingestion. On the other hand, E. coli cultures of $\mathrm{O}$ groups 44 and 142 which produced illness were isolated from diarrheal stool specimens from the volunteers in almost pure culture and they persisted for more than 7 days after ingestion, thus suggesting multiplication in the intestinal tract.

\section{DISCUSSION}

From the studies by Sakazaki et al. (1967, 1974 a), Ogawa et al. (1968), and DuPont et al. (1971), it was clear that some strains of invasive EEC serotypes probably caused disease in man by a mechanism similar to that of Shigella organisms which penetrate and multiply in the intestinal mucosal cells (LaBrec et al., 1964). Enterotoxin production may not be concerned with the pathogenicity or virulence of these organisms, although such toxins were demonstrated in some strains of O25:K1 and $\mathrm{O} 152: \mathrm{K}$. in this study, as well as in a culture of Shigella dysenteriae 1 by Keusch, Jucewicz, and Hirschman (1972).

On the other hand, the mechanism of pathogenicity of noninvasive EEC strains has not yet been explained. Recently, some investigators considered that enterotoxin production by noninvasive EEC strains accounted for their ability to cause diarrhea. Smith and Gyles (1970) showed that some EEC serotypes, often associated with infantile gastroenteritis, may produce an enterotoxin. Their finding was confirmed in the present study. As already mentioned, enterotoxin production was demonstrated in 13 of 20 strains of noninvasive EEC serotypes isolated from children and adults suffering from gastroenteritis; these serotypes are also recognized as causal agents of infantile gastroenteritis. The role of enterotoxin in the pathogenesis of $E$. coli diarrhea was first described by Smith and Halls (1967) who investigated strains isolated from piglets and calves with acute diarrhea. In the medical field, Sack and Gorbach and their co-workers (Sack et al., 1971; Gorbach, 1971; Etkin and Gorbach, 1971) reported enterotoxin production by $E$. coli strains isolated from patients suffering from cholera-like diarrhea in Calcutta. Similarly, DuPont et al. (1971) demonstrated enterctoxin production in ligated gut loop tests with two $E$. coli strains, isolated from American soldiers with diarrhea in Vietnam. These strains also caused a diarrheal syndrome resembling that of cholera in human volunteers. These authors emphasized the significance of enterotoxin production in causing diarrhea following infection with noninvasive EEC serotypes. It should be noted, however, that some strains of EEC serotypes failed to cause gut loop reactions with living cultures, although they did produce an enterotoxic factor in cultures in the present study. In contrast, with some other strains only living culture produced positive loop reactions and culture filtrates had no enterotoxic activity. In addition, R-mutant cultures from three EEC strains lost the ability of the original culture to produce a positive gut loop reaction, although their culture filtrates were still able to cause dilatation of the loop. Taylor et al. (1961) reported that $\mathrm{R}$ strains of Salmonella failed to produce positive gut loop reactions. These findings thus suggest that enterotoxin production is not the essential mechanism of pathogenesis in diarrhea due to noninvasive EEC strains. 
Taylor et al. (1958) studied the relation between histological findings and dilatation of gut loops after inoculation with EEC and reported considerable variation with different strains. Similar results were also obtained in this study. Furthermore, the contents of dilated gut segments also varied in nature. For example, some segments showed dilatation due to inflammatory exudate, whereas others merely contained serous fluid. Ligated gut loop tests have commonly been used in studies with Vibrio cholerae. Since dilatation of gut loops inoculated with $V$. cholerae and with cholera enterotoxin may be due simply to fluid accumulation, dilatation only has been emphasized in cholera studies. However, in the medical field enterotoxin production by $E$. coli strains has been studied by cholera investigators, who have frequently referred to $E$. coli diarrhea as a cholera-like syndrome (De et al., 1956; DuPont et al., 1971; Craig, 1972). However, illness caused by infection with noninvasive EEC strains in children and adults, as well as in infants, is usually gastroenteritis or occasionally enteritis or colitis, resembling salmonellosis (Costin, 1966; Sakazaki et al., 1967, 1974 a).

Taking these factors into account, the present authors do not consider that enterotoxin production is concerned in the mechanism of enteropathogenicity of noninvasive EEC, but that the ability of certain $E$. coli strain to multiply in the intestine is essential, although enterotoxin production may perhaps play an additional role in the development of the diarrheal syndrome. In another study on the enteropathogenicity of Vibrio parahaemolyticus, the authors showed that only Kanagawa-positive biotypes of the vibrio prcduce positive reactions in rabbit gut loops as well as gastroenteritis in human volunteers, although all strains of $V$. parahaemolyticus were able to produce an enterotoxic factor in the supernatant fluid of broth cultures (Sakazaki et al., $1974 \mathrm{~b}$ ). Similar consideration may apply to the pathogenesis of Salmonella gastroenteritis. Sakazaki et al. (1974 c) demonstrated enterotoxic activity in broth culture filtrates of various serotypes of Salmonella. The authors therefore consider that diarrhea due to noninvasive EEC serotypes is similar to that of Salmonella infections.

Although it was not the purpose of this study to investigate properties of E. coli enterotoxin, it is doubtful if the enterotoxic and permeability activities of broth culture filtrates of EEC are simply two manifestations of the same factor. The enterotoxic factors produced by different EEC serotypes or strains are not necessarily identical. De et al. (1953), who first employed the ligated gut loop model for studying the pathogenicity of $E$. coli cultures, stated that histopathologically there was no evidence of polymorphonuclear cell infiltration in the wall of the intestine or in the contents in loop tests showing dilatation. On the other hand, Taylor et al. (1958) emphasized the inflammatory changes occurring in the intestinal wall and stated that 'dilatation of the gut was always accompanied by purulent inflammatory change, with exudate between villi composed of cell debris and polymorphonuclear leukocytes, the villi being congested and oedematous with polymorphs migrating through the epithelium into the lumen'. The findings in the present study support those of Taylor et al. (1958). In contrast, the findings of Sack et al. (1971), Etkin and Gorbach (1971), and DuPont et al. (1971) seemed to support those of De et al. (1953). It should be noted, however, that all the E. coli strains used in studies by De et al., Sack et al., Etkin and Gorbach, and DuPont et al. were isolated in India or Vietnam from diarrheal cases resembling cholera, whereas those studied by Taylor et al. and by the present authors were isolated from patients with gastroenteritis, infantile diarrhea, or colitis 
in England or Japan, where diarrheal diseases resembling cholera are not generally seen. This might suggest the presence of some other factor(s) in bacteria or patients or both in tropical countries where cholera is common.

It is known that the symptoms produced by noninvasive EEC serotypes, Salmonella, and other enteropathogenic bacteria vary from one patient to another. DuPont et al. (1971) reported a strains of E. coli O148:H28 from a case of colitis. All the four strains of this serotype examined in the present study were, however, isolated from cases of gastroenteritis.

Enterotoxigenic E. coli strains reported by Sack and his co-workers (1971), as well as by DuPont et al. (1971) belonged to O groups $6,15,78$, or 148 , or an unidentified $\mathrm{O}$ group not previously reported as a human EEC serotype. In addition, Smith and Halls (1968) showed that in some strains the ability to prcduce enterotoxin is controlled by a plasmid. This might suggest that serotyping is of little value in identifying noninvasive EEC. It should be emphasized, however, that most of the strains which gave positive ligated loop reactions in the present study belonged to $O$ groups previously reported as EEC, while only few of the 148 strains of non-EEC group isolated from patients with diarrhea produced dilatation in gut loop tests. In their study on a large number of strains of various $E$. coli serotypes, Taylor, Wilkins, and Payne (1961) found that only strains belonging to E. coli serotypes associated with infantile gastroenteritis caused positive gut loop reactions. Sakazaki et al. (1967, 1974 a) reported that $25 \mathrm{O}$ group serotypes of EEC were associated with diarrhea in children and adults. Although enterotoxigenic E. coli strains of $\mathrm{O}$ groups 6, 78, and 148 had not previously been accepted as enteropathogenic for man, Sakazaki et al. (1974 a) described repeated isolations of these serotypes from children and adults with diarrhea. Strains of $\mathrm{O}$ groups 6 and 78 were also isolated from patients with infantile diarrhea (Nestorescu, 1954; Ewing, Davis, and Montague, 1963; Linzenmeier and Metz, 1960; Linzenmeier et al., 1961). In addition, E. coli strains belonging to $O$ group 148 were first reported by Rowe, Taylor, and Bethelheim (1970) in patients with traveller's diarrhea. It should be noted that $E$. coli strains of $O$ groups 6,78 , and 148 isolated in Japan, as well as strain O148 of Rowe et al. which was received through Dr. F. Ørskov were also enterotoxigenic in this study. The authors believe, therefore, that these O-group serotypes should be regarded as EEC, and that serotyping would be still valuable for detecting and identifying noninvasive EEC in diarrheal stools.

It seems almost self evident that ingestion of large numbers of viable organisms is necessary to produce diarrhea with Salmonella and noninvasive EEC in children and adults. Such diarrhea associated with these organisms would usually be caused by food in which sufficient multiplication had occurred.

It is of interest that two strains of $O$ groups 44 and 142, which are included in the noninvasive EEC category by Sakazaki et al. (1967, 1974 a) produced gastroenteritis in human volunteers, whereas strains not belonging to EEC serotypes, but causing positive reactions in ligated gut loop tests, failed to produce illness in volunteers even though the organisms were isolated in pure culture from cases of diarrhea. This finding also suggests that the ability to multiply in the human intestine is an essential factor in the enteropathogenicity of noninvasive $E$. coli and that only strains of the EEC serotypes may have this ability. Namioka, Urushido, and Sakazaki (1958) studied $E$. coli strains isolated from pigs affected by viral gastroenteritis (transmissible 
gastroenteritis) and described a category of $E$. coli referred to as 'toxic $E$. coli'. They considered that these toxic strains of $E$. coli were present in normal pigs, which were not affected and remained healthy. Strains which produced positive loop reactions in rabbits but failed to produce illness in human volunteers may perhaps be in the same category as the strains of toxic $E$. coli from pigs. If some other factors affect the digestive tract, toxic $E$. coli normally present in the colon might reach the small intestine and cause enteritis.

Although previous investigators used syncase broth (Finkelstein et al., 1966) for cholera enterotoxin production to demonstrate enterotoxin in $E$. coli culture, a new medium, MMV broth, was superior to the former in this study. However, MMV broth was still not entirely satisfactory, because concentration of culture filtrates was necessary to demonstrate enterotoxic activity. Further study is needed to find the cultural coditions necessary for satisfactory enterotoxin production by $E$. coli strains.

\section{REFERENCES}

Costin, I. D. (1966): Diarrhoeal disease in children and adults associated with Escherichia coli strains not belonging to enteropathogenic serotypes. Pathol. Microbiol., 29, 214-217.

CRAIG, J. P. (1972): “The enterotoxic enteropathies". pp. 125-155. In H. Smith and J. H. Pearce (ed.) Microbial Pathogenicity in Man and Animals. Cambridge Univ. Press, London.

De, S. N. AND Chatterjee, D. N. (1953): An experimental study of the mechanism of action of Vibrio cholerae on the intestinal mucous membrane. J. Pathol. Bacteriol., 66, $559-562$.

De, S. N., Bhattacharaya, K. AND SaRKAR, J. K. (1956): A study of the pathogenicity of strain of Bacterium coli from acute and chronic enteritis. J. Pathol. Bacteriol., 71, 201209.

DuPont, H. L., Formal, S. B., Hornick, R. B., Snyder, M. J., Libonati, J. P., SheAHAN, D. G., LABREC, E. H. AND KALAS, J. P. (1971): Pathogenesis of Escherichia coli diarrhea. New Engl. J. Med., 285, 1-9.

ERlandson, A. L., JR., Nemer, M. A. ANd Pearson, I. A. (1964): Characteristics of various experimental human adult virulent Escherichia coli infection in mice. J. Infect. Dis., 114, 163-168.

ETKIN, S. AND GoRBACH, S. L. (1971): Studies on enterotoxin from Escherichia coli associated with acute diarrhea in man. J. Lab. Clin. Med., 78, 81-87.

Ewing, W. H., Davis, B. R. And Montague, T. S. (1963): Studies on the occurrence of Escherichia coli serotypes associated with diarrheal disease. CDC Publication, Communicable Disease Center, Atlanta. $38 \mathrm{p}$.

Finkelstein, R. A., Atthasampuuna, P., Chulasamaya, M. And Charunmenthee, P. (1966): Pathogenesis of experimental cholera. Biologic activities of purified procholeragen A. J. Immunol., 96, 440-449.

GoRBACK, S. L. (1971): Acute diarrhea - a toxin disease ? New Engl. J. Med., 283, 44-45.

Keusch, G. T., JucewicZ, M. AND HiRschman, S. Z. (1972): Quantitative microassay in cell culture for enterotoxin of Shigella dysenteriae 1. J. Infect. Dis., 125, 539-541.

LaBrec, E. H., Schneider, H., Magnani, T. J. AND Formal, S. B. (1964): Epithelial cell penetration as an essential step in the pathogenesis of bacillary dysentery. J. Bacteriol., $88,1503-1518$.

Linzenmeier, G. AND Metz, H. (1960): E. coli O78:80B, einer der Erreger der Kälberruhr, als Ursache der Säuglingsdyspepsie. Med. Klin., 55, 1151-1152.

Linzenmeier, G., Freislederer, W., ApAK, S. AND Metz, H. (1961): Bakteriologische 
und therapeutische Beobachtungen bei Säuglingsdyspepsien, versucht durch klassifische und neue Serotypen von Esch. coli. Münch. Med. Wschr., 103, 1398-1403.

NAMIOKA, S., URUSHIDO, M. AND SAKAZAKI, R. (1958): Escherichia coli isolated from transmissible gastroenteritis in pigs. Japan. J. Med. Sci. Biol., 11, 141-158.

Nestorescu, N. (1954): Tulburarile acute de nutritie si digestie la sugar si copilul mic. Pediatria, Buc., 2, 22-31.

OGAWA, H., NAKAMURA, A. AND SAKAZAKI, R. (1968): Pathogenic properties of enteropathogenic Escherichia coli from diarrheal children and adults. Japan. J. Med. Sci. Biol., $21,333-349$.

$\Phi_{\mathrm{RSKOV}}, \mathrm{I} ., \Phi_{\mathrm{RSKOV}}, \mathrm{F}$. AND Rowe, B. (1973): Three new Escherichia coli O antigens, O154, O155 and O156, and one new K antigen, K94. Acta Path. Micriobiol. Scand., Sec. B., 81, 59-63.

Rowe, B., TAylor, J. AND Bethelheim, K. A. (1970): An investigation of traveller's diarrhoea. Lancet, 1, 1-5.

Sack, R. B., Gorbach, S. L., Banwell, J. G., Jacobs, B., Chatterjee, B. D. ANd MITRA, R. C. (1971): Enterotoxigenic Escherichia coli isolated from patients with severe cholera-like disease. J. Infect. Dis., 123, 378-385.

SAKAZAKI, R., TAMURA, K. AND SAITO, M. (1967): Enteropathogenic Escherichia coli associated with diarrhea in children and adults. Japan. J. Med. Sci. Biol., 20, 389-399.

SAKAZAKI, R., TAMURA, K. AND NAKAMURA, A. (1974 a): Further studies on enteropathogenic Escherichia coli associated with diarrhea in children and adults. Japan. J. Med. Sci. Biol., 27, 7-18.

Sakazaki, R., Tamura, K., NaKamura, A., Kurata, T., Gohda, A. and Kazuno, Y. (1974 b): Studies on enteropathogenic activity of Vibrio parahaemolyticus using ligated gut loop model in rabbits. Japan. J. Med. Sci. Biol., 27, 35-44.

SAKAZAKi, R., TAmURA, K., Nakamura, A. AND Kurata, T. (1974 c): Enteropathogenic and enterotoxigenic activities on ligated gut loops in rabbits of Salmonella and some other enterobacteria isolated from human patients with diarrhea. Japan. J. Med. Sci. Biol., 27, $45-48$.

SELÉNEY, B. (1955): Experimental Shigella keratoconjunctivitis (A preliminary report). Acta Microbiol. Acad. Sci. Hung., 2, 289-296.

Skerman, F. J., Formal, S. B. AND FAlKow, S. (1972): Plasmid-associated enterotoxin production in a strain of Escherichia coli isloated from humans. Infect. Immunity, 5, 622624.

Smith, H. W. AND Halls, S. (1967): Studies on Escherichia coli enterotoxin. J. Pathol. Bacteriol., 93, 531-543.

SMITH, H. W. AND Halls, S. (1968): The transmissible nature of the genetic factor in Escherichia coli that controls enterotoxin production. J. Gen. Microbiol., 52, 319-334.

SMITH, H. W. AND GyLES, C. L. (1970): The effect of cell-free fluids prepared from cultures of human and animal enteropathogenic strains of Escherichia coli on ligated intestinal segments of rabbits and pigs. J. Med. Microbiol., 3, 403-409.

Smith, H. W. AND LiNGgood, M. A. (1971): The transmissible nature of enterotoxin production in a human enteropathogenic strain of Escherichia coli. J. Med. Microbiol., 4, 301-305.

STAMP, L. (1947): The preservation of bacteria by drying. J. Gen. Microbiol., 1, 251-265.

TAYlOR, J., MAltby, M. P. AND PAYNE, J. M. (1958): Factors influencing the response of ligated rabbit gut segments to injected Escherichia coli. J. Pathol. Bacteriol., 76, 491-499.

TAYLOR, J. AND WILKINS, M. P. (1961): The effect of Salmonella and Shigella on ligated loops of rabbit gut. Indian J. Med. Res., 49, 544-549. 
TAYlor, J., Wilkins, M. P. AND PAyNe, J. M. (1961): Relation of rabbit gut reaction to enteropathogenic Escherichia coli. Brit. J. Exptl Pathol., 42, 43-48.

TAYLOR, J. AND BETHELHEIM, K. A. (1966): The action of chloroform-killed suspension of enteropathogenic Escherichia coli on ligated rabbit gut segments. J. Gen. Microbiol., 42, 309-313. 